\title{
Politics, Aesthetics, and the Critical Humanities: Revisiting an American Tradition?-An Interview with Ross Posnock
}

\section{Cécile Roudeau and Ross Posnock}

\section{(2) OpenEdition}

1 Journals

Electronic version

URL: https://journals.openedition.org/transatlantica/17520

DOI: 10.4000/transatlantica. 17520

ISSN: $1765-2766$

Publisher

Association française d'Etudes Américaines (AFEA)

\section{Electronic reference}

Cécile Roudeau and Ross Posnock, "Politics, Aesthetics, and the Critical Humanities: Revisiting an American Tradition?-An Interview with Ross Posnock ", Transatlantica [Online], Hors-série | 2021, Online since 01 October 2021, connection on 11 October 2021. URL: http://journals.openedition.org/ transatlantica/17520 ; DOI: https://doi.org/10.4000/transatlantica.17520

This text was automatically generated on 11 October 2021.

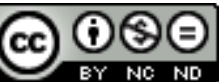

Transatlantica - Revue d'études américaines est mise à disposition selon les termes de la licence Creative Commons Attribution - Pas d'Utilisation Commerciale - Pas de Modification 4.0 International. 


\title{
Politics, Aesthetics, and the Critical Humanities: Revisiting an American Tradition?-An Interview with Ross Posnock ${ }^{1}$
}

\author{
Cécile Roudeau and Ross Posnock
}

Ross Posnock is Anna S. Garbedian Professor of the Humanities at Columbia University, where he studies and teaches US and European literature and intellectual history. Ross Posnock was Andrew Hilen Professor of American Literature at the University of Washington before teaching in the English department at New York University from 2000 to 2004. From 1998 to 2017 he was series editor of Cambridge Studies in American Literature and Culture (Cambridge University Press) and is a contributing editor of Raritan and American Literary History. In 1994 he was awarded a Guggenheim Fellowship. In 2009 he was elected to the American Academy of Arts and Sciences. He is currently writing a book about American sophistication, a selective history from the eighteenth century until now. We are proud to count him among the members of the scientific committee of Transatlantica and very honored that he has agreed to this interview. 


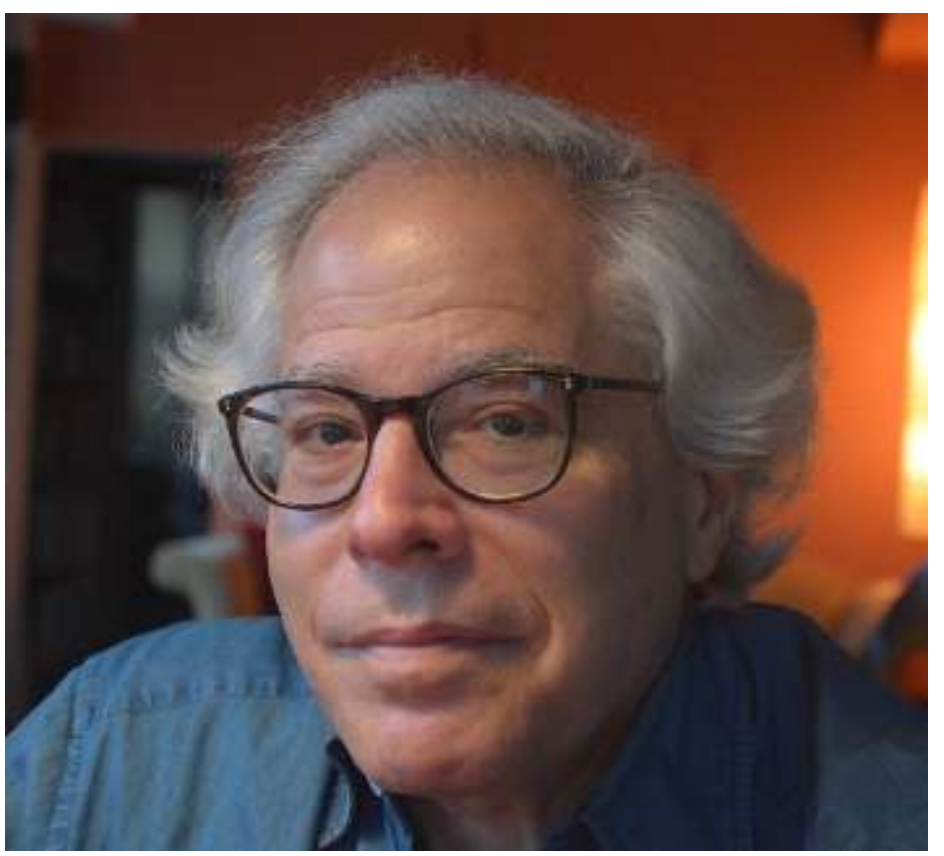

CÉcIle ROUdeAU: Thank you for accepting this interview on the occasion of the twentieth anniversary of Transatlantica. We are very honored to have you as a member of the scientific committee, and it is a wonderful opportunity for us to have your perspective on questions related to the state of American studies today. Let me start with an obvious question: in a post-Trump era, how does one teach, or how does one read and think about, US literature? More provocatively, maybe, how can one be a professor of American literature today?

Ross Posnock: That's a very basic, important question. Even the way to consider the question is strange-we wouldn't think of a change of presidents as having much to do with the teaching of literature. But of course, we've learned that it has a great deal to do with it. Just to sum it up, today's a very different environment than, let's say, the Obama years. As soon as Trump took over, many people, including myself, thought that the fact of having an unabashed racist in the White House would traumatize the academic Left, fomenting a sense of embattlement and betrayal, of pervasive racism. This was manifested in the assumption that the American English departments would reflect that racism, and so the effort was to combat it in all possible ways. Which is a strange logic that became gradually apparent with the spring riots over George Floyd's death and the aftermath of that.

I don't know if people outside of the United States are aware of what a number of prominent English departments did at that point, which was to post statements. On their website, for instance, the University of Chicago made a statement, part of it includes that "English as a discipline has a long history of providing esthetic rationalizations for colonialism and exploitation and anti-blackness. We attend to both literature's capacity to normalize violence and derive pleasure from its esthetic expression. We believe that undoing persistent recalcitrant anti-blackness in our discipline of literature and in our institutions must be the collective responsibility of all faculty here and elsewhere." That became the most well-known example, but a number of departments issued statements like that, and what struck me was that the very interracial character of these worldwide protests against police brutality and for social justice, racial justice, the very fact that they were so integrated, indicated a 
kind of success that English departments and humanities in general had achieved over the last decade or so, I mean the success in articulating a critique of the Enlightenment that propelled students into a heightened political awareness. And so English departments, and of course the humanities in general, could have taken that moment of global social unrest as a measure of their success in helping foster critical consciousness. Instead, there wasn't a whisper of that kind of logic that I am suggesting; there was just an outpouring of self-accusation, self-condemnation, a sense of guilt. And it struck me as bizarre because US English departments are the most unracist public institutions in the United States by far. And not least because this critique has become de rigueur for many decades now. So, it was as if the effectiveness of that teaching had ignored that this was an historical moment when the teaching was confirmed, politically, confirmed globally, and instead the teaching was inverted into a completely different message of guilt-mongering, where literature departments become complicit, as the statement says. "We believe that undoing recalcitrant antiblackness in our discipline must be the collective responsibility of all faculty here and elsewhere." When it's precisely that project of antiblackness that has been at the forefront of US literature departments for decades now.

C.R.: Yes, even in France, I'm struck by the demise of critical thinking. Critical thinking now is thought to be, in a way, not radical enough. Literature teaching has shifted towards, or back to, a more category-based thinking and forgotten about deconstruction. The way you're putting it is as if the humanities were ready to sacrifice themselves...

R.P: Yes, that's a good way to put it.

C.R: But is that really the solution? I tend to believe in the critical force and the radicality of critical thinking, the political efficacy of a non-categorial, or nonbinary, thinking. The movement back to identity, for example, is of course a move that has some political efficacy, but also tends to reify what it has taken us years to de-essentialize.

R.P.: Absolutely. The fetish of Identity as sacred. I could give an anecdote based on my experience. I never had any problems in class with a clash of political beliefs or students' political beliefs being disrespected. But on the first week of a class I was giving on James Baldwin and Henry James, I quoted Baldwin's self-description of being attacked verbally in Greenwich Village in the 40s as a "faggot." I read this passage, a well-known passage by Baldwin, and later that evening, three students dropped the class and then a fourth later dropped the class a few weeks later, who told me that the students had been offended. They felt "unsafe" after the quoted word "faggot" was uttered by me. Let me add that all the students who quit were white. There were about four or five black students in the class. The black students in the class had no negative reaction at all. So one of the students urged me to turn it into a teaching moment where we would discuss this question with the rest of the class. I said that wouldn't be a good idea because I have strong views on it, by which I meant I didn't respect what the students did, and so I didn't want to be publicly forced to say that. I wanted to just forget about it because I don't think there's really an open debate about it. I've heard about it also in French departments, humanities departments, they all have stories to tell like this. For example, Arnold Rampersad, you know, the biographer of Langston Hughes, was giving a very interesting talk on Fitzgerald last week, and during the question period a woman said, what do you think of the teachers or administrators who insist that they take books like Gatsby off the reading list because they have either unflattering portraits of Jews or blacks within, 
you know, very small moments, but some people are urging that The Great Gatsby, be banned. And Rampersad heard this and said that's just sheer stupidity. And I later wrote him a note thanking him for his bluntness, but he said that it wasn't easy.

C.R.: And then you ban Twain, you ban Fitzgerald, you even maybe ban Baldwin, for that matter, whereas perhaps the one way of addressing these questions would be to just, well, go back to what the text does with these binaries, and often deconstructs them. It seems that this verb has been "forgotten" these days, or maybe "banned." Whereas I for one believe we may need more, not less, deconstruction today, especially a deconstruction of the categories that we are again taking for granted after all these years.

R.P.: Absolutely. I mean, the sad irony in Baldwin is that he makes explicit in several essays that literature is what denies security, that literature is a discourse that's about the denial of fixed assumptions, of certainties, of certain categories. And so, for the student to simply quit, to resign from the course out of a sense of being "unsafe" is so shockingly in need of a discussion, but they made the discussion impossible since they left the course. They don't raise their hand and say, I'm disturbed by that word. Let's talk about that word, you see.

C.R. I do. And I would even be tempted to say that when you take a literature class, you are not looking for safety. A literature class is anything but a safe space. As a continuation of what we were just saying, I'd like to ask you a question about your position as a professor of the humanities at Columbia. That's your title. I imagine it must have been a rather obvious title, say, 10 years ago, maybe 20 years ago. But today it sounds increasingly, if not from another age, at least not quite in tune with some recent turns in the "humanities." I'm thinking here of the posthuman, the nonhuman turns, the attack on humanism as a blind or even dangerous humanocentrism. What is your perspective on these turns? And, more broadly, how would you describe the state of the humanities and the validity, or not, of this word in this title of yours?

R.P.: One answer is that the humanities remains indispensable as the practice of critical thinking, for the Enlightenment is also the counter-Enlightenment, that is, the Enlightenment itself is dialectical, a crosscurrent. Take Rousseau, for instance, who's critiquing all the other philosophical systems. There's no party line to the Enlightenment. Say, it's a conflict already. The only legitimate humanities is a discourse that will be willing to entertain its own demise, its own severest interrogations. Rather than a defense of blind, pious worship of the past, or a holding up of some "tradition" as an act of veneration. That kind of humanities is basically useless at this point. If we think of that tradition, which has been a notable tradition in the United States among conservatives, that we have to guard our cultural patrimony, uphold it, well, it's never made clear just what this patrimony consists of. Luckily, the canonical US writers are all radical, all interrogative and skeptical. Obviously, a Thoreau, Melville, Dickinson, Emerson can't be corralled into any conformist point of view or any even supportive point of view. There are endless debates about their political usefulness, but there's no definitive answer to any of that. So those canonical nineteenth-century American writers would be a sort of tradition that you could venerate because they despise veneration, the passive worship of tradition. If there's a built-in self-interrogation that would make the humanities vital, it is this and not a pious reverence of the past. I am of course parroting Emerson here, even pleas for skepticism are endangered by complacency. So, things like the transhuman or the antihuman are welcome as inevitable intellectual or political social developments that challenge, let's say, the impulse of the humanities to universalize or to dominate, or smugly to be imperial. These 
attacks in their own backyard are welcome as the basis of their vitality, we could say. But the point is that my kind of answer is disposed of because it lacks any polemical bite to it.

C.R.: Maybe we need to think anew what we mean by, let's say, the difference between polemical and critical, and also where the political can stand. Can we still be political without being ideological? It seems to me that ideology is back within the humanities, and literature and ideology, for me, don't mix too well.

R.P.: Pascal says, at least in English, that all of our problems derive from the inability to sit alone in one's room, ineradicable restlessness, that is. One might say that the chronic agitation and guilt of US English departments derive from the inability to accept the fact that literature is not political action. Literature, as you're saying, is not ideology. Teachers and students who have always wished that literature could be an instrument of politics, or could work hand in glove with politics, so as to give what they do in the classroom and on the page a relevance or drama or intensity of meaning, are involved in a fantasy, a basic self-deception that goes on-the inability to accept the limits of literature. To accept what literature is, its artifice, its fictionality, its masquerade, you know, all the things that a Nabokov foregrounds, all the playfulness, that whole tradition of Sterne and Cervantes, that whole selfquestioning, the mocking origins of the novel. It's a form of play, and our increasingly strident political atmosphere has no patience for that, or interest in. It's just related to another dismissive word "estheticism." These are problems that are replayed generation after generation. The sad thing is that there's no end to it. So, the fact that Baldwin proclaims his investment and identity in literature means that it's not just a racial identity for him. And that's either unforgivable for some people, who critique Baldwin as estheticized, apolitical, or they imagine another Baldwin, a fantasy Baldwin who's actually a militant political figure, when he's much more complicated than that. His priority is literature. I mean, Henry James was his hero! [laughter] That was the force of teaching a course on James and Baldwin. Even colleagues would say, why? What do they have in common? I said, well, Baldwin always said that James was his favorite novelist. A black militant in 68 asked Baldwin for a reading list of important books you should read, and the first one was... The Princess Casamassima! So that's the kind of fact that is worth pondering, you see?

C.R.: I do! I don't know how it is in the US, but here in France, or in Europe, we are more and more invited to write applications for collaborative projects, fellowships, etc. And each time, if you are a scholar working in the humanities, in literature in particular, the question is: what is the impact of this projected work? How can you justify yourselves as a rubric that needs government funding? And so, as a literary scholar, you need to justify yourself and the "use" of the humanities. Why aren't we allowed to just say that, yes, indeed, we are "playing," but, beware, because play is the beginning of all revolutions. I mean, Sterne, you know, and eighteenth-century literature was all about play. Who says it has had no political impact?

R.P.: Absolutely. The pleasure of the conversation, a place of possibility, of seeing what happens, where ideas drift. Well, that's why I blame Rousseau on a lot of these problems, his hatred of play, of acting, of urbanism, of cosmopolitanism, that is also deep in American culture. It's really ineradicable. I'm working on a book on sophistication, which is another word that is a red flag to the bull, in which there will be a discussion of Franklin's autobiography as a reply to Rousseau's Confessions. Franklin wanted to show the sort of artifice of human nature as benign instead of moral disaster. 
C.R.: What you're writing proves very bold and audacious these days, it seems to me, I mean, the references you are putting forward in a recent essay, such as Greek sophistry, Saint Augustine, Pascal, Montaigne, Milton, and this notion of sophistication and a defense of esthetics as what is at the heart of what we are doing as literary scholars. How do you see your intervention in the fields of US literary studies? Do you perceive it as a bold move, as writing against the grain? Or do you see it as just something you've been doing for years? In other words, has your own perception of your project changed over the years?

R.P.: That's a good question. I think I am in a minority position, to use a popular word [laughter]. But of course, that, to me, makes it important. I mean, I'm the only person in my department who teaches Henry James regularly. So, if I don't, then, he'll be off the curriculum, somebody an English major will never encounter. So that's the pedagogical dimension in terms of my own writing. A concept like sophistication is basically a disaster in terms of drawing an audience, a certain kind of audience, as someone said to me. I offered a graduate course on sophistication and it was pretty dismal simply because the students didn't know who we were talking about; they had no idea who Noël Coward or Cary Grant or people like Fred Astaire were. They didn't know these basic icons of sophistication, let alone other people. It's not a domain that they're familiar with. Merely the whiff of elitism emanating from "sophistication" is enough to terrify them. But, rather than surrender to that as ignorance, I think it's important to educate, but it's sort of an uphill climb.

But I did want to say something that's not answering your question. Going back to this sense of race in English departments as an open wound or a source of guilt or self-laceration. In the last decade, if you ask anyone paying attention in US English departments what is the most distinctive new development, you would have to say the emergence of a brilliant group of black intellectuals, people like Saidiya Hartman, her book Wayward Lives, Beautiful experiments, and a fellow at NYU named Fred Moten, and Nate Mackey, the poet, and Brent Edwards, Claudia Rankine and Arthur Yafa. These are all sort of virtuoso critics and thinkers and artists, creators, visionaries even. And they have established an entire field or network or a way of thinking that's the most distinctive new thing in literature, in the humanities. And it's further evidence of the US English departments fostering and nurturing black talent. So, the notion of insisting on a sense of guilt and complicity for our society's recalcitrant antiblackness seems misplaced, in other words.

It is a renaissance time for black studies. I mean, the black studies I've just been talking about has very little to do with the black studies of the 70s and $80 \mathrm{~s}$. This is the most philosophically sophisticated literary intellectual kind of work that's being done now. And it's something that the academy should be proud of. But that's not the notion that's workable, that notion has no political power, no political charge to it; this sense of celebrating would smack of self-congratulation or quietism or passivity or be regarded as anti-political.

C.R.: It's interesting how we cannot acknowledge what, in fact, we, as an institution, are fostering.

R.P.: Yes, that's so. In other words, we're denying history. By insisting on this hyperpoliticization, we end up denying history, what we've actually achieved. Because where did these black scholars, these brilliant people come from? They came from decades of being nurtured in a predominantly white academy, and that's one of their -these scholars'-strengths-that they don't play the race card, let's say. They are 
very cosmopolitan, very unparochial. No racial ghettos like those the black arts movement of the 70 s was obsessed with. None of that.

C.R.: Seeing what's happening in the US, in African American studies, as new renaissance is very interesting, and also what you're saying about this cosmopolitanism. Our journal is called Transatlantica. And accordingly, we are trying to create a transatlantic conversation, which is not necessarily an easy thing to do, for all the reasons that we've mentioned. I was wondering what you would have to say on the national paradigms that are still very much our work base in the humanities and literature. We still take for granted that this is US literature, or this is French literature, or British literature. I don't mean that we should get rid of these categories, but at least we should, I believe, deconstruct them and try to take some distance from them. The transnational turns, the hemispheric turns, have tried to do so, but I'm not so sure we have moved away from these national boundaries in our analyses.

R.P.: I think they're stubbornly persistent. We've invented many intricate methodological deconstructions of national paradigms, but they don't seem to break down the object. The paradigm itself remains, because it's the easiest way to hire people. It's almost a reflex we automatically think of. For example, you know, colonial American literature, which is a thin field, struggling. But we still think of it as American literature, even though for the last decade it's been profoundly enlarged by Caribbean and all sorts of other global, hemispheric studies. So even as we enriched them, even as we enrich each of the national paradigms, it still remains, as you're saying, the simplistic name, the national identity.

C.R.: Sometimes I dream of an academia where you could introduce yourself as a professor of literature. Period.

R.P.: Wonderful! And I have been seeing this irrelevance of national identities in writing a book on sophistication. Because I had to learn about Greek rhetoric and French court society in the seventeenth century and La Rochefoucauld and people like that, who are basic to understanding what conversation is, or hypocrisy and truth and manners and etiquette-all of these terms are kind of complex and they are, as you know better than I, debated throughout the seventeenth- and eighteenthcentury French, Italian, English culture. So, to even touch the subject, you have to open up your American subject matter to multiple cultures and literatures. No, no national boundaries are really that relevant at a certain point.

I think all of those movements, the transnational, the hemispheric, have been worthwhile in forcing us to see the artifice and the imperialism of these basic categories. Even if we can't dispense with them yet, we've probably enriched them significantly in a way that makes them more valuable, even if they're still stubbornly important.

C.R.: It reminds me of the debate around disciplines. Maybe it's more true in France, but in French academia, disciplines are something that we still believe in very stubbornly, even as we all endorse the necessity of the cross-disciplinary. Historians or literary scholars have their own "methods" and "tools", and don't always find it easy to converse, let alone combine their approaches. Now, you obviously read philosophy, read literature, know history: what do you think of disciplinary niches?

R.P.: Well, I think we have to do a few things at once: we have to respect the boundaries. There are national literatures, and then, we have to see how porous the boundaries are, how permeable. When I started studying American literature in the late 60 s and early $70 \mathrm{~s}$, it was sort of an intellectual backwater because it was so obedient to the national boundaries and so hostile to French theory, for instance. If 
you studied American literature, it meant you were basically hostile to theory or any kind of intense intellectual discourse because you had your little canon and that was it. So, thank God, that's changed a great deal. Yes, you're right about the stubborn persistence of the national paradigm. But it's a different paradigm at this point.

C.R.: Thank you so much, Ross, for this conversation. Conversation is, alas, a forgotten art, to be revived! We're looking forward to reading more on American sophistication.

\section{BIBLIOGRAPHY}

\section{Selected Works by Ross Posnock}

POSNOCK, Ross. Henry James and the Problem of Robert Browning, Athens, GA: University of Georgia Press, 1985.

POSNOCK, Ross. The Trial of Curiosity: Henry James, William James, and the Challenge of Modernity. New York: Oxford University Press, 1991.

POSNOCK, Ross. Color and Culture: Black Writers and the Making of the Modern Intellectual. Cambridge, MA: Harvard University Press, 1998.

POSNOCK, Ross, ed. The Cambridge Companion to Ralph Ellison. Cambridge, UK: Cambridge University Press, 2005.

POSNOCK, Ross. Philip Roth's Rude Truth: The Art of Immaturity. Princeton: Princeton University Press, 2006.

POSNOCK, Ross. Renunciation: Acts of Abandonment by Writers, Philosophers and Artists. Cambridge, MA: Harvard University Press, 2016.

POSNOCK, Ross. “American Sophistication.” Oxford University Press Research Encyclopedia. doi.org/10.1093/acrefore/9780190201098.013.1252. Published online: 17 December 2020. Accessed 4 October 2021.

\section{Works cited}

FITZGERALD, Francis Scott. The Great Gatsby. New York: Charles Scribner's Sons, 1925.

FRANKLIN, Benjamin. Autobiography. 1793. Ed. Joyce E. Chaplin. New York: W. W. Norton, 2012.

HARTMAN, Saidiya, Wayward Lives, Beautiful experiments: Intimate Histories of Social Upheaval. New York: Norton, 2019.

JAMES, Henry. The Princess Casamassima. London: MacMillan, 1886.

RAMPERSAD, Arnold. The Life of Langston Hughes. I, Too, Sing America. Vol.1. Oxford: Oxford University Press, 1986.

ROUSSEAU, Jean-Jacques. The Confessions. 1782. Translated from the French by John Michael Cohen. London: Penguin Classics, 1973. 
NOTES

1. This interview was conducted on 29 June 2021.

\section{AUTHORS}

\section{CÉCILE ROUDEAU}

Université de Paris

ROSS POSNOCK

Columbia University 